\title{
Germination and initial development of Simira gardneriana seedling under water stress and at different temperatures
}

\author{
Fabrícia N. de Oliveira ${ }^{1}$, Jessica R. de Oliveira ${ }^{2}$, Salvador B. Torres ${ }^{3}$, \\ Rômulo M. O. de Freitas ${ }^{4} \&$ Narjara W. Nogueira ${ }^{3}$ \\ ${ }^{1}$ Universidade Federal Rural do Semi-Árido/Centro de Engenharia. Mossoró, RN. E-mail: fabricia@ufersa.edu.br \\ ${ }^{2}$ Universidade Federal Rural do Semi-Árido/Centro de Ciências Biológicas e da Saúde. Mossoró, RN. E-mail: jessica_rgn@hotmail.com \\ ${ }^{3}$ Universidade Federal Rural do Semi-Árido/Centro de Ciências Agrárias. Mossoró, RN. E-mail: sbtorres@ufersa.edu.br (Corresponding author); \\ narjara.nogueira@ufersa.edu.br \\ ${ }^{4}$ Instituto Federal de Educação, Ciência e Tecnologia Baiano/Campus Valença. Valença, BA. E-mail: romulomagno_23@hotmail.com
}

Key words:

Rubiaceae

Caatinga

osmotic potential

forest species

\begin{abstract}
A B S T R A C T
The germination of seeds is affected by many factors, including water availability and temperature. This study aimed to evaluate the effects of water stress and different temperatures on germination and initial development of S. gardneriana M. R. Barbosa \& Peixoto seedlings. The experiment was carried out in a completely randomized design, in a $7 \mathrm{x} 4$ factorial scheme, with seven potentials $(0 ;-0.1 ;-0.2 ;-0.3 ;-0.4 ;-0.5$ and -0.6 $\mathrm{MPa})$ and four temperatures $\left(25,30,35\right.$ and $\left.20-30{ }^{\circ} \mathrm{C}\right)$, with four replicates of 25 seeds. The analyzed variables were germination, percentage of normal seedlings, germination speed index, seedling length (shoot and root) and dry weight (shoot and root). There is a decrease in the germination and vigor of the seeds as the water potential decreases, being less affected under the temperature of $25^{\circ} \mathrm{C}$ and very accelerated at $35^{\circ} \mathrm{C}$. The tolerance of $S$. gardneriana seed germination to water stress is variable between the temperatures and limiting to the formation of normal seedlings from the potential $-0.5 \mathrm{MPa}$ at temperatures of 25 to $30^{\circ} \mathrm{C}$ and -0.4 and $-0.2 \mathrm{MPa}$ for $20-30$ and $35^{\circ} \mathrm{C}$, respectively.
\end{abstract}

\section{Palavras-chave:}

Rubiaceae

Caatinga

potencial osmótico

espécie florestal

\section{Germinação e desenvolvimento inicial de plântulas de Simira gardneriana sob estresse hídrico e em diferentes temperaturas}

\begin{abstract}
RES U M O
A germinação de sementes é afetada por vários fatores destacando-se a disponibilidade de água e a temperatura. Objetivou-se avaliar o efeito do estresse hídrico e diferentes temperaturas na germinação e no desenvolvimento inicial de plântulas de S. gardneriana M. R. Barbosa \& Peixoto. O experimento foi realizado sob delineamento inteiramente casualizado, em esquema fatorial $7 \times 4$ sendo sete potenciais $(0 ;-0,1 ;-0,2 ;-0,3 ;-0,4 ;-0,5$ e - 0,6 MPa) e quatro temperaturas $\left(25,30,35\right.$ e $\left.20-30^{\circ} \mathrm{C}\right)$, com quatro repetições de 25 sementes. As variáveis analisadas foram germinação, porcentagem de plântulas normais, índice de velocidade de germinação, comprimento de plântulas (parte aérea e raiz) e massa seca (parte aérea e raiz). Ocorre diminuição na germinação e no vigor das sementes à medida que decresce o potencial osmótico sendo menos afetados sob a temperatura de $25^{\circ} \mathrm{C}$ e bastante acelerados na de $35^{\circ} \mathrm{C}$. A tolerância da germinação de sementes de $S$. gardneriana ao estresse hídrico é variável entre as temperaturas e limitante na formação de plântulas normais a partir do potencial $-0,5 \mathrm{MPa}$ sob as temperaturas de 25 e $30^{\circ} \mathrm{C}$ e de $-0,4$ e $-0,2 \mathrm{MPa}$ para as de $20-30$ e $35^{\circ} \mathrm{C}$, respectivamente.
\end{abstract}




\section{INTRODUCTION}

Simira gardneriana M. R. Barbosa \& Peixoto, native to the Brazilian semi-arid region and popularly known as 'pereiro-vermelho' or 'pereiro-de-tinta', is exclusive to the arboreal-arbustive Caatinga of the central region of Northeast Brazil and can reach up to $7 \mathrm{~m}$ of height, being successfully employed in street tree planting, as well as in the composition of mixed reforestations. In addition, it has potential to be used in activities of rural constructions and as forage, which makes this species a key point for socio-environmental studies in the Northeastern semi-arid region (Barbosa \& Peixoto, 2000; Lorenzi, 2009).

S. gardneriana annually produces an abundant amount of viable seeds that are spread by the wind, at short distances (Lorenzi, 2009). However, it is known that the seeds, when dispersed by the wind, are subject to a set of factors that affect germination, such as water availability and temperature. Thus, it becomes important to understand the mechanisms that make the seeds of some species able to germinate under adverse conditions (Rosa et al., 2005).

Polyethylene glycol has been successfully used to simulate the effects of water deficit on plant species (Almeida et al., 2014), determining the point of tolerance to drought (Hamayoun et al., 2011).

For each species, there is a critical value of osmotic potential below which germination does not occur, as well as a temperature that influences seed imbibition speed also on the biochemical reactions that define the entire germination process. For instance, seeds of Piptadenia moniliformis do not germinate at osmotic potentials equal to or lower than -1.2 $\mathrm{MPa}$ at temperatures of 25 and $30^{\circ} \mathrm{C}$ (Azerêdo et al., 2016).

On the other hand, the limit for the germination of Apeiba tibourbou seeds is between - 0.4 and - $0.6 \mathrm{MPa}$ (Guedes et al., 2013). Similarly, the germination of Amburana cearensis occurred at the temperature of $30{ }^{\circ} \mathrm{C}$ up to the limit of -0.6 MPa (Almeida et al., 2014).

Thus, this study aimed to evaluate the effect of water stress on the germination and initial development of S. gardneriana seedlings at different temperatures.

\section{Material ANd Methods}

Ripe fruits of $S$. gardneriana were collected in matrix trees of the municipality of Afrânio-PE, Brazil ( $8^{\circ} 30^{\prime} 42^{\prime \prime} \mathrm{S} ; 41^{\circ}$ $00^{\prime} 36^{\prime \prime} \mathrm{W} ; 540 \mathrm{~m}$ ) and the seeds were manually removed and processed in the Reference Center for Recovery of Degraded Areas of the Caatinga (CRAD), which belongs to the Federal University of the São Francisco Valley (UNIVASF), Petrolina, PE. Then, the seeds were sent to the Laboratory of Seed Analysis of the Department of Plant Sciences of the Federal Rural University of the Semi-Arid Region (UFERSA), Mossoró-RN, placed in Kraft paper bags and stored in cold chamber $\left(10^{\circ} \mathrm{C}\right.$ and $50 \%$ of relative humidity of the environment) until the beginning of the experiment, in March 2014.

The experiment was set in a completely randomized design in a $7 \times 4$ factorial scheme, which corresponded to seven osmotic potentials $(0 ;-0.1 ;-0.2 ;-0.3 ;-0.4 ;-0.5 ;-0.6 \mathrm{MPa})$ and four temperatures $\left(25,30,35\right.$ and $\left.20-30^{\circ} \mathrm{C}\right)$, with four replicates of 25 seeds.

The analyzed variables were germination, percentage of normal seedlings, germination speed index, seedling length (shoots and roots) and dry weight (shoots and roots).

The different osmotic potentials were obtained through the values proposed by Villela et al. (1991), using polyethylene glycol (PEG 6000). Then, the germination test was installed, in which the seeds were placed on two sheets of paper towel, covered with a third sheet and arranged in the form of a roll, moistened with distilled water (control) or solution of PEG 6000 at different potentials $(-0.1 ;-0.2 ;-0.3 ;-0.4 ;-0.5 ;-0.6$ $\mathrm{MPa})$, in the amount equivalent to 2.5 times the dry weight of the substrate.

The replicates of each treatment were placed in transparent plastic bags, to avoid water loss through evaporation, and maintained in Biochemical Oxygen Demand (B.O.D.) germinators regulated at constant temperatures of 25,30 and $35^{\circ} \mathrm{C}$ and alternated temperature of $20-30^{\circ} \mathrm{C}$, with photoperiod of $8 \mathrm{~h}$. When necessary, the paper was moistened again with distilled water (control) and with the respective solutions of PEG 6000.

The evaluations were daily performed after the test was installed for a period of 30 days. From this point on, the germination stabilized and the seeds considered as germinated were those with primary root of at least $2 \mathrm{~mm}$ of length (Borghetti \& Ferreira, 2004) and positive geotropic curvature. In addition, the formation of normal seedlings with primary root and perfect shoots (Brasil, 2009) was evaluated at the end of the test, with results expressed in percentage.

The germination speed index was evaluated together with the germination test, with daily counts of the number of germinated seeds at the same time, from 6 to 30 days after sowing, calculated according to the formula proposed by Maguire (1962).

At the end of the germination test, the length of the normal seedlings (roots and shoots) was evaluated (Brasil, 2009). A ruler graduated in centimeters was used to measure the shoots (base of the plant until the insertion of cotyledon leaves) and roots (base of the plant until the tip of the main root), and the results were expressed in $\mathrm{cm}$ seedling ${ }^{-1}$.

The normal seedlings of the previous evaluation were divided into roots and shoots, placed in paper bags and dried in an oven at $65^{\circ} \mathrm{C}$ for $72 \mathrm{~h}$, until constant weight. After this period, the samples were weighed on an analytical scale (0.001 g) and the results were expressed in g seedling ${ }^{-1}$.

The obtained data were statistically analyzed by F test, with follow-up analysis performed always when the interaction was significant. The results were subjected to regression analysis ( $\mathrm{p}$ $<0.05$ ) and the model was selected considering the biological explanation and the significance of the regression mean square using the equation that best fitted to the data. The analyses were performed using the statistical program Sisvar (Ferreira, 2011).

\section{Results AND Discussion}

There was significant interaction in all analyzed variables. In addition, the temperatures and osmotic potentials 
Table 1. Summary of the analysis of variance for the variables germination $(\mathrm{G})$, percentage of normal seedlings (PN), germination speed index (GSI), shoot length (SL), root length (RL), shoot dry matter (SDM) and root dry matter (RDM) of Simira gardneriana seeds subjected to different osmotic potentials and temperatures

\begin{tabular}{lccccc}
\hline \multirow{2}{*}{ F values } & \multicolumn{5}{c}{ Sources of variation } \\
\cline { 2 - 6 } GL & Temperature (T) & Osmotic potentials (OP) & Interaction (T x OP) & Overall mean & CV (\%) \\
G (\%) & 3 & 6 & 18 & - & - \\
PN (\%) & $123.30^{* *}$ & $108.45^{* *}$ & $8.55^{* *}$ & 66.43 & 14.62 \\
GSI & $223.34^{* *}$ & $220.91^{* *}$ & $13.91^{* *}$ & 45.21 & 17.50 \\
SL (cm) & $190.54^{* *}$ & $212.20^{* *}$ & $6.46^{* *}$ & 1.03 & 15.00 \\
RL (cm) & $203.73^{* *}$ & $461.40^{* *}$ & $37.78^{* *}$ & 0.97 & 18.52 \\
SDM (g) & $263.32^{* *}$ & $92.39^{* *}$ & $9.64^{* *}$ & 4.84 & 20.74 \\
RDM (g) & $52.95^{* *}$ & $198.96^{* *}$ & $9.31^{* *}$ & 0.01 & 21.43 \\
\hline
\end{tabular}

${ }^{*}$ Significant at 0.01 probability level by F test; CV - Coefficient of variation; DF - Degrees of freedom

significantly and independently interfered with all response variables (Table 1).

For the temperatures, germination is reduced with the decrease in the osmotic potential (Figure 1A). This reduction was observed from the potentials of $-0.3 \mathrm{MPa}$ at the temperature of $25^{\circ} \mathrm{C}$; $-0.2 \mathrm{MPa}$ at 30 and $20-30^{\circ} \mathrm{C}$ and $-0.1 \mathrm{MPa}$ at $35^{\circ} \mathrm{C}$. From these potentials on, germination was negatively affected and reached $23 \%\left(25^{\circ} \mathrm{C}\right), 22 \%\left(30^{\circ} \mathrm{C}\right), 33 \%\left(20-30^{\circ} \mathrm{C}\right)$ and $0 \%\left(35^{\circ} \mathrm{C}\right)$.

The potential of $-0.6 \mathrm{MPa}$ caused reductions in germination of $64,74,77$ and $100 \%$ at the temperatures of $20-30,25,30$ and $35{ }^{\circ} \mathrm{C}$ respectively, in comparison to the values obtained for the control $(0.0 \mathrm{MPa})$. On the other hand, the control treatment $(0.0 \mathrm{MPa})$ resulted in $90 \%$ of germination at $25{ }^{\circ} \mathrm{C}, 97 \%$ at 30 ${ }^{\circ} \mathrm{C}, 91 \%$ at $20-30{ }^{\circ} \mathrm{C}$ and $73 \%$ at $35^{\circ} \mathrm{C}$ (Figure $1 \mathrm{~A}$ ).

As observed in the present study, in Zeyheria montana seeds there was also germination at $25^{\circ} \mathrm{C}$, which decreased with the increment of PEG 6000 concentration from $87 \%$ (0.0 MPa) to $20 \%(-0.6 \mathrm{MPa})$, reaching zero at the potential of $-0.8 \mathrm{MPa}$ (Kratz et al., 2013). For Erythrina falcata seeds, the germination significantly decreased from the potential of $-0.2 \mathrm{MPa}$ on in PEG 6000 solutions, at $25^{\circ} \mathrm{C}$, with absence of germination at $-1.0 \mathrm{MPa}$ (Pelegrini et al., 2013).

It can be noted that the $S$. gardneriana seeds are extremely sensitive to water stress and the germination was substantially reduced as the osmotic potential of the substrate decreased. In addition, when this test was conducted at the highest temperature $\left(35^{\circ} \mathrm{C}\right)$, there was a rapid reduction in germination, compared with the temperatures of 25,30 and $20-30^{\circ} \mathrm{C}$, confirming that the temperature of $35^{\circ} \mathrm{C}$ can not be used in the germination test (Figure 1A).

The reduction in seed germination percentage due to thermal and water stresses may occur due to the very low or very high temperatures (Oliveira et al., 2014) or even to the PEG 6000 solutions, thus possibly compromising the availability of water and oxygen to the seeds, because polyethylene glycol has high viscosity and high molecular weight (Hamayoun et al., 2011).

The data of percentage of normal seedlings (Figure 1B) fitted to a quadratic model for the temperatures of 25,30 and $35{ }^{\circ} \mathrm{C}$ and to the third-degree polynomial model for the alternated temperature of $20-30{ }^{\circ} \mathrm{C}$. The reduction of the osmotic potential caused decrease in the normal seedlings for all temperatures from the potential of $-0.1 \mathrm{MPa}$ on, while for germination this potential led to reduction only at the highest temperature $\left(35^{\circ} \mathrm{C}\right)$.

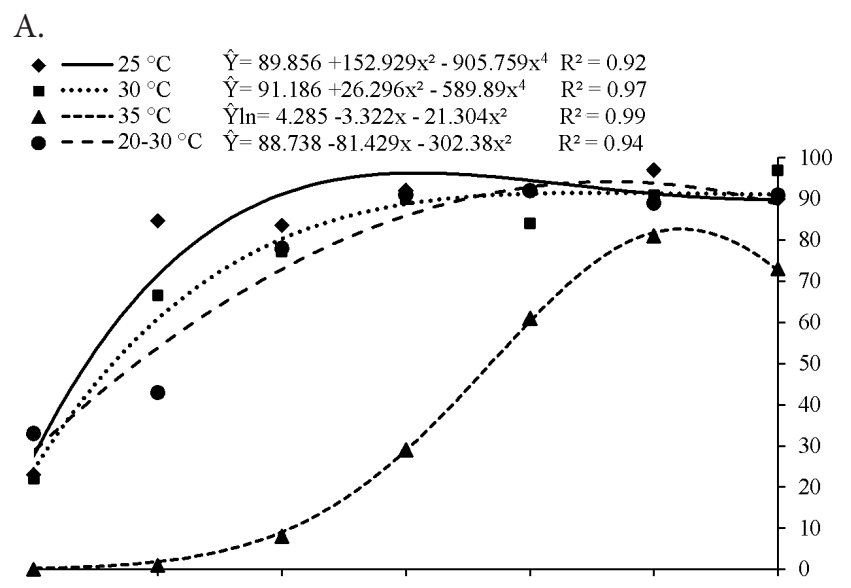

B.

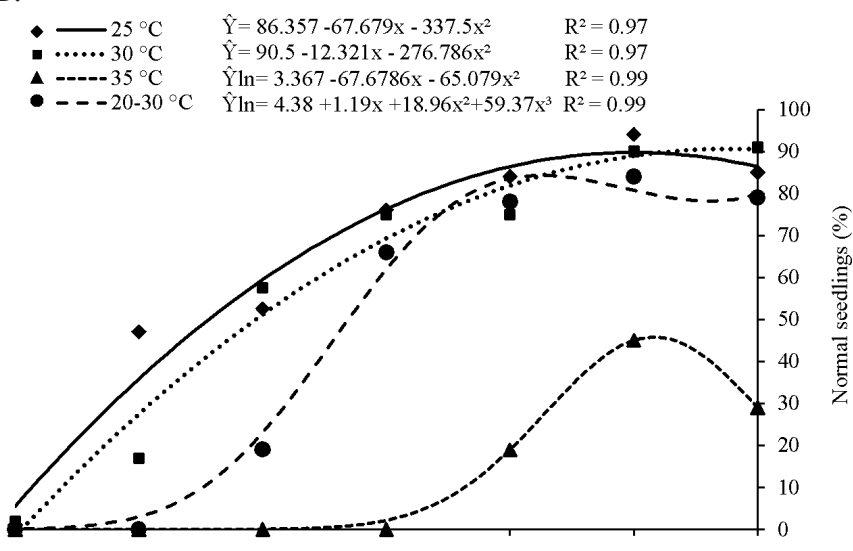

C.
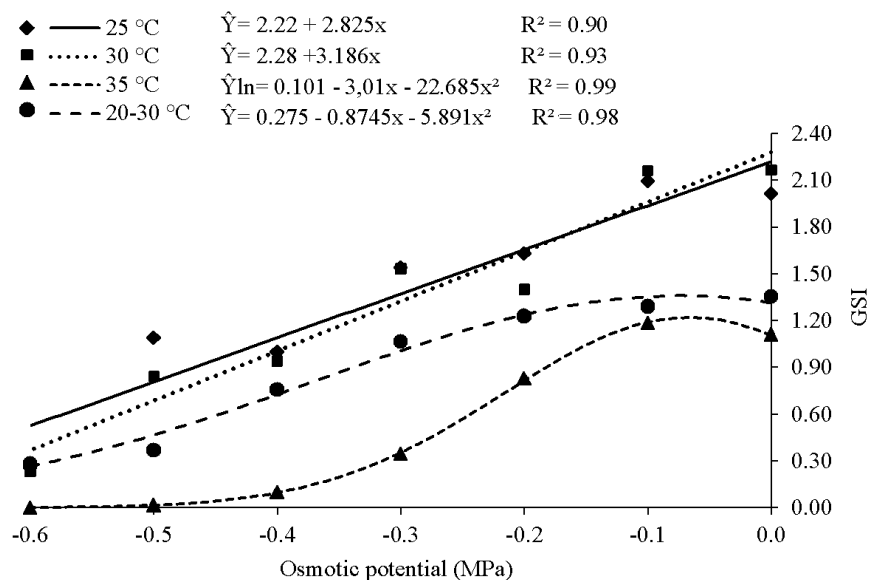

Figure 1. Germination (A), normal seedlings (B) and germination speed index-GSI (C) of Simira gardneriana seeds subjected to different osmotic potentials and temperatures 
At all temperatures, at the potential of $-0.1 \mathrm{MPa}$, there was higher percentage of normal seedlings than in the control, which can be explained as a probable control of imbibition, which acts as an osmotic regulator and thus allows physiological activities, such as the accumulation of sugars, organic acids and ions, activating the initial metabolism and, consequently, the radicle protrusion (Santos et al., 2011).

For the temperature of $35^{\circ} \mathrm{C}$ in the range between -0.3 and $-0.6 \mathrm{MPa}$, there was no formation of normal seedlings, although the seeds produced radicle until the potential of -0.5 $\mathrm{MPa}$, which was also observed for the alternated temperature of $20-30^{\circ} \mathrm{C}$ at the potentials from -0.5 to $-0.6 \mathrm{MPa}$ (Figure $1 \mathrm{~B}$ ).

In the comparison of the seeds at the different temperatures, the absence of formation of normal seedlings at the potential of $-0.6 \mathrm{MPa}$ is justified by the effect of PEG 6000 .

The sensitivity of S. gardneriana seeds to water stress in the formation of normal seedlings was always higher when the osmotic potential decreased and, at the temperatures of 25 and $30^{\circ} \mathrm{C}$, the percentage of normal seedlings was higher than that obtained for the other temperatures.

A similar result also occurred with Piptadenia moniliformis seeds, when exposed to temperatures of 25 and $30^{\circ} \mathrm{C}$. They showed high number of normal seedlings until the osmotic potential of $-0.6 \mathrm{MPa}$, with sharp reductions until -1.2 $\mathrm{MPa}$ and, from this point on, there were no normal seedlings (Azerêdo et al., 2016). In seeds of Amburana acreana, there was a reduction in the formation of seedlings as the osmotic potential of the substrate decreased, being null at $-0.8 \mathrm{MPa}$, at $30{ }^{\circ} \mathrm{C}$ (Bello et al., 2008).

The obtained GSI results for S. gardneriana seeds were more sensitive to water deficit than the percentages of germination and normal seedlings, because from the potential of $0 \mathrm{MPa}$ on, at the temperatures of 25 and $30^{\circ} \mathrm{C}$ and from $-0.1 \mathrm{MPa}$ on, at 20-30 and $35^{\circ} \mathrm{C}$, there was a reduction of the indices (Figure 1C).

The results of the present study demonstrate that $S$. gardneriana seeds not subjected to water stress obtained higher germination speed and, as the water availability decreased in the substrate, the seeds needed a longer time for imbibition and germination, evidencing lower germination speed. Similar results were observed for the forest species Anadenanthera colubrina (Rego et al., 2011), Apeiba tibourbou (Guedes et al., 2013), Amburana cearensis (Almeida et al., 2014) and Jacaranda pteroides (Dutra et al., 2014).

At the osmotic potentials from -0.1 to $-0.6 \mathrm{MPa}$, the shoot length of the seedlings decreased for all studied temperatures, in comparison to the control treatment $(0 \mathrm{MPa})$. The highest value of shoot length was observed at the potential of $0 \mathrm{MPa}$ at $30^{\circ} \mathrm{C}(3.95 \mathrm{~cm})$, while the lowest one $(0.85 \mathrm{~cm})$ occurred at the alternated temperature of $20-30^{\circ} \mathrm{C}$ (Figure $2 \mathrm{~A}$ ).

The main root length decreased from the osmotic potential of $0 \mathrm{MPa}$ on, at the temperatures of 30 and $35^{\circ} \mathrm{C}$. On the other hand, at the temperatures of $20-30$ and $25^{\circ} \mathrm{C}$, between the potentials of 0 and $-0.2 \mathrm{MPa}$, there was an increase in main root length and a reduction from this potential on (Figure 2B).

Root length was less affected by the effects of water stress than shoot length, which can be related to the fact that the seeds, within a limited range of stress, invest more in roots than in shoots, an important mechanism of acclimation to drought (Almeida et al., 2014).

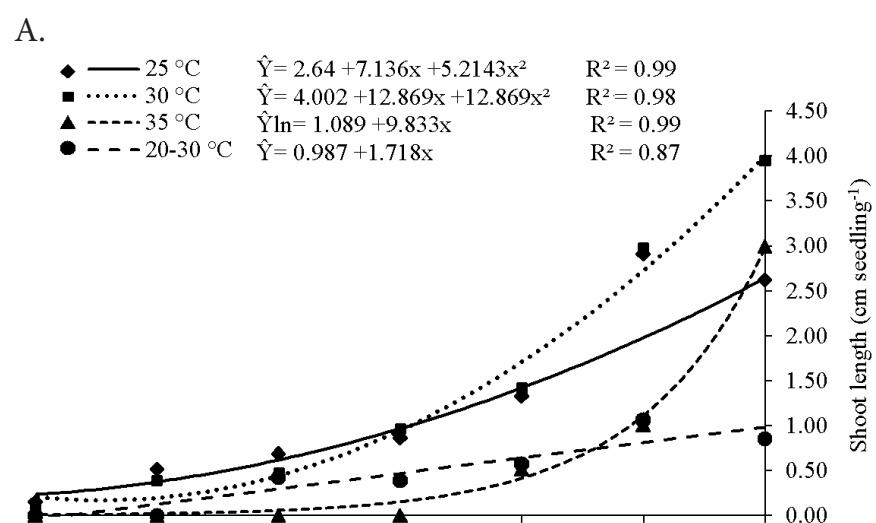

B.

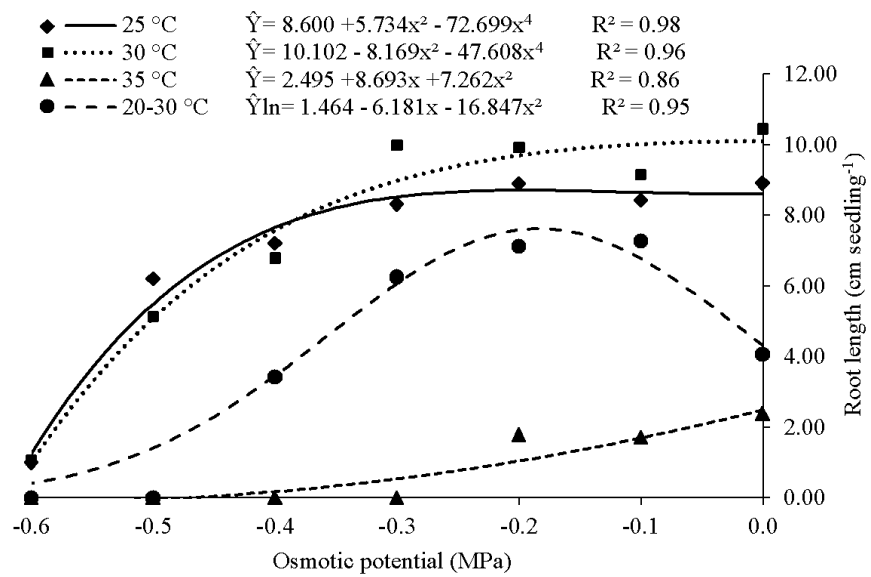

Figure 2. Shoot length (A) and root length (B) of Simira gardneriana seedlings subjected to different osmotic potentials and temperatures

As observed for the percentage of normal seedlings and germination speed index, the $S$. gardneriana seeds subjected to the temperatures of 25 and $30^{\circ} \mathrm{C}$ resulted in higher means of root length of the seedlings, which did not differ, and the lowest values occurred at $35^{\circ} \mathrm{C}$.

Root dry matter and shoot dry matter of S. gardneriana seedlings at the four tested temperatures showed a similar behavior. The values of dry matter decreased with the increment in water stress, caused by the reduction of the osmotic potential. However, at the temperature of $25^{\circ} \mathrm{C}$, the reduction in dry matter content was lower than at the other temperatures (Figure 3).

For the temperatures of 25 and $30^{\circ} \mathrm{C}$, shoot dry matter decreased linearly as the osmotic potential of the substrate decreased, changing from 0.026 and 0.025 g seedling $^{-1}$ at the potential of $0 \mathrm{MPa}$ to 0.002 and $0.001 \mathrm{~g}$ seedling ${ }^{-1}$, respectively, at the potential of $-0.6 \mathrm{MPa}$ (Figure $3 \mathrm{~A}$ ). The highest value of root dry matter of the seedlings resulted from seeds that were not subjected to water stress, being equal to $0.012 \mathrm{~g}$ seedling ${ }^{-1}$ at the temperature of $25^{\circ} \mathrm{C}$ and, from $-0.2 \mathrm{MPa}$ on, root dry matter reduced quadratically (Figure $3 \mathrm{~B}$ ).

In addition, besides the water stress caused by polyethylene glycol, which is harmful to seed germination, the highest temperature $\left(35^{\circ} \mathrm{C}\right)$ had the greatest contribution to the reduction of shoot and root dry matter. This occurs because the gradual increase in temperature affects the availability of water, influencing to a lesser and greater degree the growth of roots and shoots of the seedlings, respectively. In seeds of other species from the Caatinga biome, such as 'angico-de-bezerro' 
A.

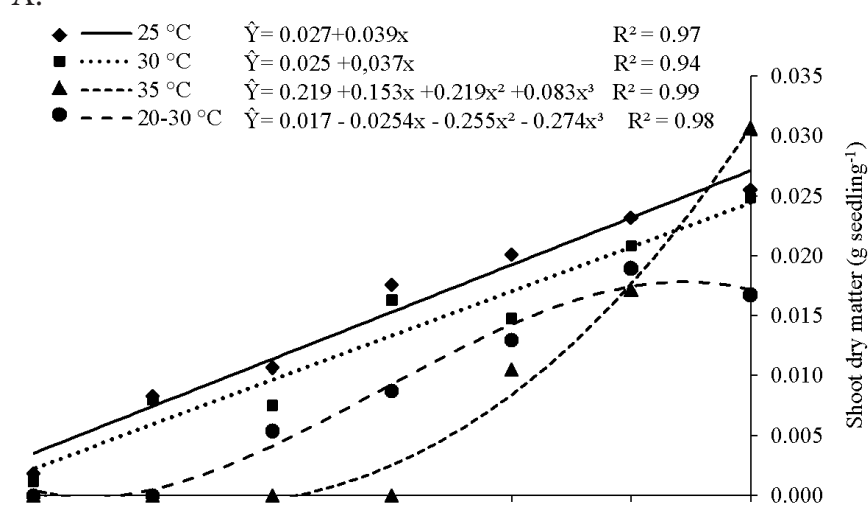

B.

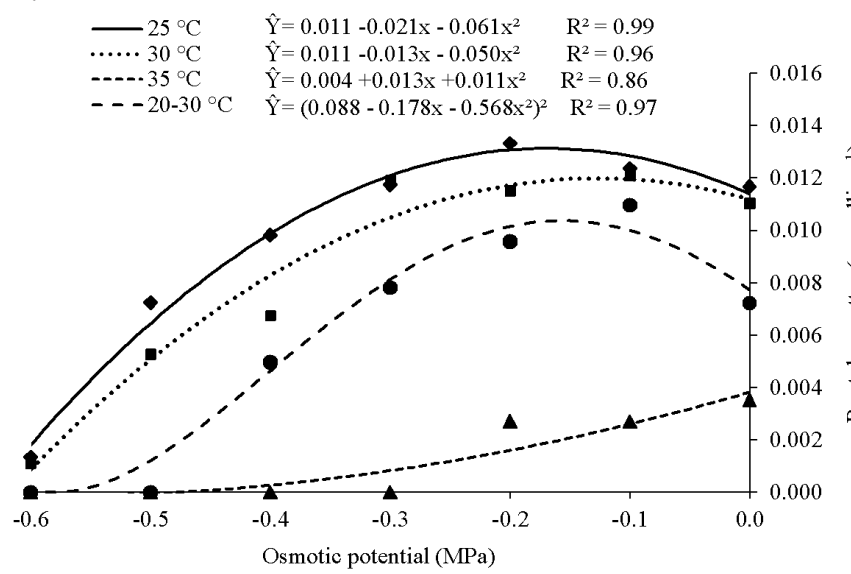

Figure 3. Shoot dry matter (A) and root dry matter (B) of Simira gardneriana seedlings subjected to different osmotic potentials and temperatures

(Azerêdo et al., 2016) and 'cumaru' (Almeida et al., 2014), the reduction of the osmotic potential also led to significant decreases in the dry matter of the seedlings.

The values of germination followed the same trends of the variables that reflect seed vigor, indicating that the reduction in the osmotic potential of the medium influenced the vigor and germination of $S$. gardneriana seeds under the temperature conditions. Many other forest species also showed reductions in seed germination and vigor, in varied degrees (Bello et al., 2008; Rego et al., 2011; Guedes et al., 2013; Pelegrini et al., 2013; Almeida et al., 2014; Dutra et al., 2014; Azerêdo et al., 2016) with the decrease in the osmotic potential.

\section{Conclusions}

1. S. gardneriana seeds are sensitive to water stress, being less and more affected at the temperatures of 25 and $35^{\circ} \mathrm{C}$, respectively.

2. The tolerance of S. gardneriana seed germination to water stress is variable among the temperatures and limiting to the formation of normal seedlings from the potential of $-0.5 \mathrm{MPa}$ on at the temperatures of 25 and $30^{\circ} \mathrm{C}$ and from -0.4 and -0.2 $\mathrm{MPa}$ on, for $20-30$ and $35^{\circ} \mathrm{C}$, respectively.

\section{ACKnowledgments}

To the CRAD/UNIVASF, Petrolina-PE, especially Ph.D. José Alves de Siqueira Filho, for providing the seeds used in the experiment.

\section{Literature Cited}

Almeida, J. P. N. de; Pinheiro, C. L.; Lessa, B. F. da T.; Gomes, F. M.; Medeiros Filho, S. Estresse hídrico e massa de sementes na germinação e crescimento de plântulas de Amburana cearensis (Allemão) A. C. Smith. Revista Ciência Agronômica, v.45, p.777787, 2014. http://dx.doi.org/10.1590/S1806-66902014000400016 Azerêdo, G. A. de; Paula, R. C.; Valeri, S. V. Germinação de sementes de Piptadenia moniliformis Benth. sob estresse hídrico. Ciência Florestal, v.26, p.193-202, 2016. http://dx.doi. org/10.5902/1980509821112

Barbosa, M. R. V.; Peixoto, A. L. A new species of Simira (Rubiaceae, Rondeletieae) from Northeastern Brazil. Novon, v.10, p.110-112, 2000. http://dx.doi.org/10.2307/3393006

Bello, E. P. de B. C. e S.; Albuquerque, M. C. de F. E.; Guimarães, S. C.; Mendonça, E. A. F. de. Germinação de sementes de Amburana acreana (Ducke) A. C. Sm. submetidas a diferentes condições de temperatura e de estresse hídrico. Revista Brasileira de Sementes, v.30, p.16-24, 2008. http://dx.doi.org/10.1590/S010131222008000300003

Borghetti, F.; Ferreira, A. G. Interpretação de resultados de germinação. In: Ferreira, A. G.; Borghetti, F. (org.). Germinação: Do básico ao aplicado. 2.ed. Porto Alegre: Artmed, 2004. p.209-222.

Brasil. Ministério da Agricultura, Pecuária e Abastecimento. Regras para análise de sementes. Ministério da Agricultura, Pecuária e Abastecimento. Secretaria de Defesa Agropecuária. Brasília: MAPA/ACS, 2009. 399p.

Dutra, T. R.; Massad, M. D.; Matos, P. S.; Oliveira, J. C. de; Sarmento, M. F. Q. Germinação e crescimento inicial de plântulas de carobinha-do-campo submetido ao estresse hídrico e salino. Agropecuária Científica no Semiárido, v.10, p.39-45, 2014.

Ferreira, D. F. Sisvar: A computer statistical analysis system. Ciência e Agrotecnologia, v.35, p.1039-1042, 2011. http://dx.doi. org/10.1590/S1413-70542011000600001

Guedes, R. S.; Alves, E. U.; Viana, J. S.; Gonçalves, E. P.; Lima, C. R. de; Santos, S. do R. N. dos. Germinação e vigor de sementes de Apeiba tibourbou submetidas ao estresse hídrico e diferentes temperaturas. Ciência Florestal, v.23, p.45-53, 2013. http://dx.doi. org/10.5902/198050988438

Hamayoun, H.; Daliri, M. S.; Mehrabi, P. Study of PEG stress effects on wheat (Triticum aestivum L.) cultivars at germination stage. Middle-East Journal of Scientific Research, v.9, p.71-74, 2011.

Kratz, D.; Bassaco, M. V. M.; Nogueira, A. C. Influência do estresse hídrico na germinação de Zeyheria montana. Journal of Biotechnology and Biodiversity, v.4, p.140-145, 2013.

Lorenzi, H. Árvores brasileiras: Manual de identificação e cultivo de plantas arbóreas nativas do Brasil. v.3. 1.ed. Nova Odessa: Instituto Plantarum, 2009. 384p.

Maguire, J. D. Speed of germination aid in selection and evaluation for seedling and vigour. Crop Science, v.2, p.176-177, 1962. http:// dx.doi.org/10.2135/cropsci1962.0011183X000200020033x

Oliveira, G. M.; Matias, J. R.; Ribeiro, R. C.; Barbosa, L. G.; Silva, J. E. S. B.; Dantas, B. F. Germinação de sementes de espécies arbóreas nativas da Caatinga em diferentes temperaturas. Scientia Plena, v.10, p.1-6, 2014.

Pelegrini, L. L.; Borcioni, E.; Nogueira, A. C.; Koehler, H. S.; Quoirin, M. G. G. Efeito do estresse hídrico simulado com $\mathrm{NaCl}$, manitol e PEG (6000) na germinação de sementes de Erythrina falcata Benth. Ciência Florestal, v.23, p.511-519, 2013. http://dx.doi. org/10.5902/198050989295 
Rego, S. S.; Ferreira, M. M.; Nogueira, A. C.; Grossi, F.; Sousa, R. K. de; Brondani, G. E.; Araujo, M. A.; Silva, A. L. L. da. Estresse hídrico e salino na germinação de sementes de Anadenanthera colubrina (Veloso) Brenan. Journal of Biotechnology and Biodiversity, v.2, p.37-42, 2011.

Rosa, L. S.; Felippi, M.; Nogueira, A. C.; Grossi, F. Avaliação da germinação sob diferentes potenciais osmóticos e caracterização morfológica da semente e plântula de Ateleia glazioviana Baill (timbó). Cerne, v.11, p.306-314, 2005.
Santos, A. R. F. dos; Silva-Mann, R.; Ferreira, R. A.; Brito, A. de S. Water pre-hydration as priming for Moringa oleifera Lam. seeds under salt stress. Tropical and Subtropical Agroecosystems, v.14, p.201-207, 2011.

Villela, F. A.; Doni Filho, L.; Siqueira, E. L. Tabela do potencial osmótico em função da concentração de polietileno glicol 6000 e da temperatura. Pesquisa Agropecuária Brasileira, v.26, p.19571968, 1991. 